\title{
MAJOR TELERENTHENGOGRAM INDICATORS IN PEOPLE WITH VARIOUS GROWTH TYPES OF FACIAL AREA
}

\section{Dmitry Domenyuk ${ }^{1}$, Michael Porfyriadis ${ }^{1}$, Sergey Dmitrienko²}

\author{
${ }^{1}$ Department of general practice dentistry \\ and child dentistry, Stavropol State Medical \\ University, Stavropol, Russia \\ 2 Department of Dentistry, Pyatigorsk Medical- \\ Pharmaceutical Institute Pyatigorsk-32, \\ Stavropol Region, Russia
}

\section{Correspondence address:}

Department of general practice dentistry and child dentistry, Stavropol state medical university of Ministry of healthcare, 310, Mira Street, Stavropol, Russia 355017. E-mail:domenyukda@mail.ru, tel: $+7(918) 870-1205$.

ABSTRACT - The results of the study and the comparison of the head lateral teleroentgenogram, involving 292 persons (both sexes) in their first adulthood period, featuring physiological occlusion of permanent teeth, helped identify the occurrence of different growth types of the facial area of the head (vertical, neutral, horizontal). The analysis of lateral teleroentgenograms included evaluation of the mandible angle size, the total Bjork angle, the ration between the posterior and the anterior face height, the Ricketts face angle, the angle between the occlusal and mandibular planes, and the angle shaped by the skull base plane and the mandibular plane. The obtained measurements allow stating that most people with physiological occlusion reveal the neutral type of the facial part growth $(61.99 \pm 2.84 \%)$, while the horizontal and the vertical types of growth were observed in $30.48 \pm 2.69 \%$ and $7.53 \pm 1.55 \%$ of the total number of the participants, respectively.

KEYW ORDS - physiological occlusion; facial area of head; teleroentgenogram; jaw growth type.

\section{INTRODUCTION}

The issues of the facial skull growth have been the focus of experts' attention for the last four decades. One of the criteria for assessing the maxillofacial area status is the jaw growth. The type of the jaw growth is recommended to be evaluated based on the data obtained through the head teleroentgenogram examination in the lateral projection $[4,11,17,25,28,30,34]$.

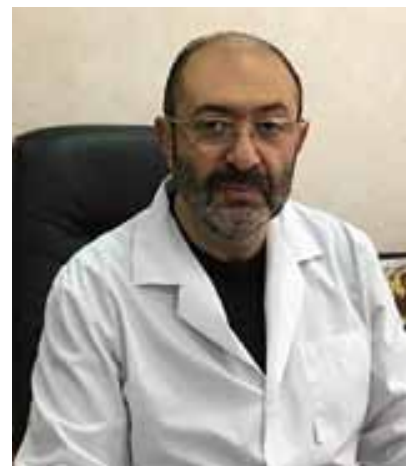

Michael Porfyriadis, Doctor of Medicine, Professor

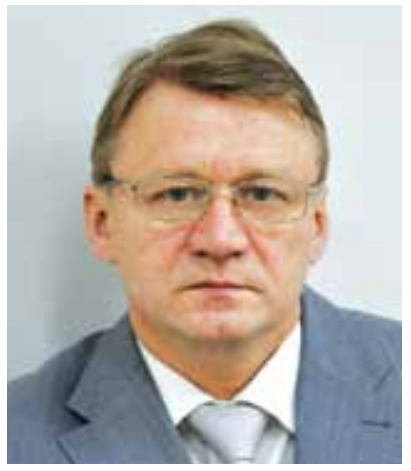

Sergey Dmitrienko Doctor of Medicine, Professor, Head of Department
Currently, there are three major types of jaw growth known - neutral, horizontal and vertical. The growth type is determined subject to several interdependent parameters, including the total Bjork angle, the ratio of the face front height to the rear height, the lower gonial angle, the Ricketts face angle. Comparing the obtained actual values with the tabulated values allows estimating the type of the jaw growth $[5,12,26,32,37,40]$.

Clinical orthodontics recommends evaluating the jaw growth type while selecting treatment for occlusion disturbances in various directions $[1,3,7,9,14,18,21,23,27,31]$.

The neutral type of jaw growth is considered the most favorable one for treating occlusion anomalies. Treating mesial occlusion and deep occlusion at the vertical growth type is preferable than treating distal occlusion. The horizontal type of jaw growth makes the treatment of deep and mesial occlusion complicated yet is viewed as favorable in case of treating distal occlusion $[2,6,8,10,16,20,22,29,33,35,38,41]$.

The available scientific literature offered us no account of the most common types of growth for the jaw bones, nor for the facial part, in people with physiological occlusion. Noteworthy is the opinion of specialists claiming that the varieties of gnathic, dental face, an of the dental arches, which are to be found at physiological occlusion, manifest a wide range of shapes and sizes, as well as in the anterior teeth position, at protrusion or retraction $[13,15,19,24,36,39,42]$.

All the above has laid the grounds for the aim of this study. 
Identifying the features of the types of facial part growth according based on lateral projection teleroentgenogram data obtained from people with physiological occlusion.

\section{MATERIALS AND METHODS}

Teleradiographic study was performed in 292 people belonging to the age group of the first adulthood period (21-35), with physiological occlusion of the permanent teeth. The main indicator of the growth type for the gnathic face part was the lower jaw angle as measured between the tangent lines to the branch and the body of the lower jaw. One sign was not sufficient to determine the growth type, due to which we evaluated the total Bjork angle, the percentage ratio of the face back and front heights, the angle shaped by the skull base plane and the mandibular plane, as well as other parameters. To study the lateral teleroentgenogram, we employed the major points used for determining the growth type $-\boldsymbol{N}$ (nasion), $\boldsymbol{S}$ (sella), $\boldsymbol{A r}$ (articulare), Ba (basion), Go (gonion), $M e$ (menton), Gn (gnation), A (subspinal point), B (supramental point),Pt (pterigoidea), C (condylen), and others (Fig. 1).

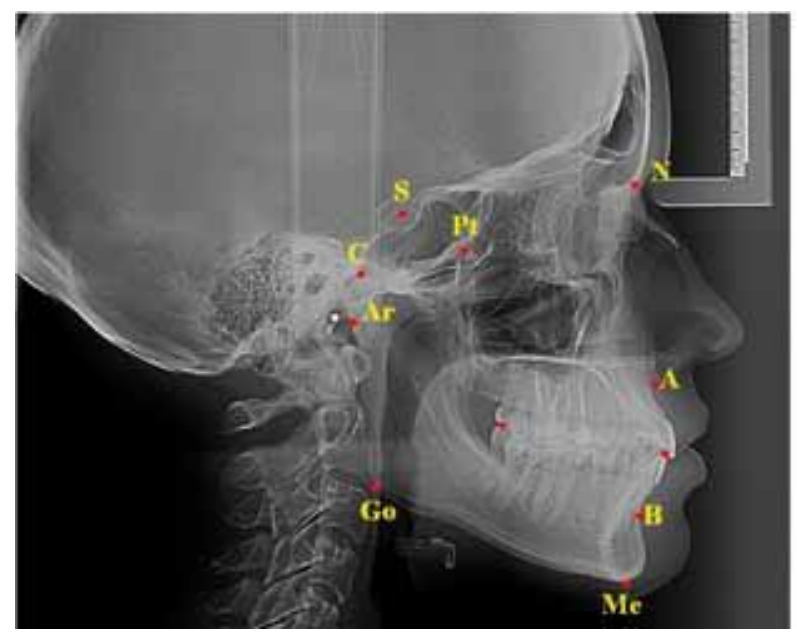

sion) point to the Me (menton) point. The measurement for the rear height was done from the middle of the Turkish saddle ( $\mathrm{S}$, sella) to the lower jaw angle at the point (gonion) Go. The angle at by the skull base plane $(\mathrm{N}-\mathrm{S})$ and the mandibular plane $(\mathrm{Me}-\mathrm{Gn})$ was calculated as well. In addition, we determined the angle between the occlusal and mandibular planes, where the occlusal line was drawn from the incisor point to the distal cusp of the second lower molar. The Ricketts face angle was measured based on the location of the Pt-Me line regarding the $\mathrm{Ba}-\mathrm{N}$ line.

Following the aims of the study, the patients were divided into three groups. Group 1 included patients whose indicators mostly corresponded to the neutral growth type of the facial part of the head. Change in the indices was indicative of either the horizontal or the vertical type of the facial part growth. Literature states that the neutral type of growth has the total Bjork angle of $393-399^{\circ}$, the angle of the lower jaw varies from 119 to $123^{\circ}$, the percentage of the face rear height to the front height $(\mathrm{S}-\mathrm{Go} \times 100 / \mathrm{N}-\mathrm{Me})$ is to be found within 62-65\%. Concerning the angle shaped by the skull base plane $(\mathrm{N}-\mathrm{S})$ and the mandibular plane (angle $\mathrm{NL}-\mathrm{ML}$ ), a value of $29-35^{\circ}$ indicates the neutral type of growth. The lower gonial angle $(\mathrm{N}-\mathrm{Go}-\mathrm{Me})$ at the

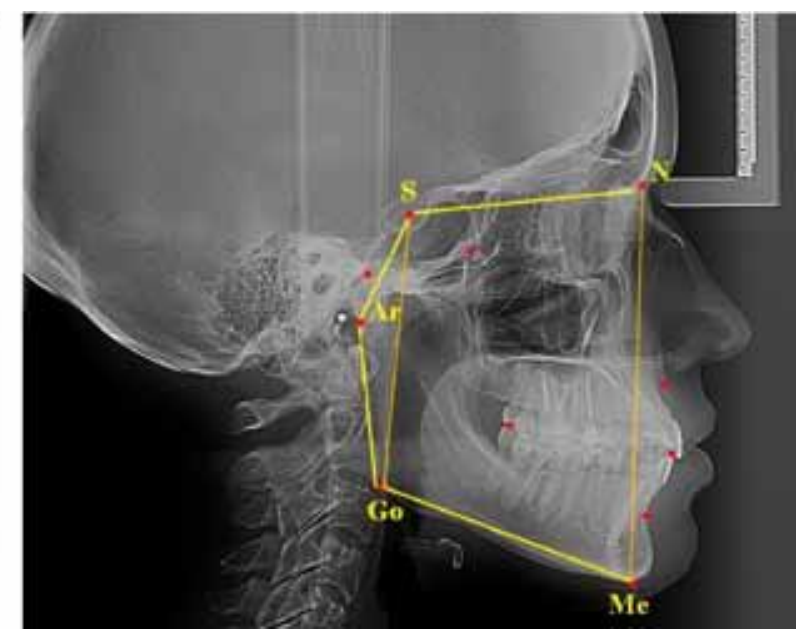

Fig. 1. Teleroentgenogram of a patient with the location of the major points (a) and parameters (b) for identifying the jaw growth type

The indicated points were connected with lines with the angles between them determined, or the percentage ratio of the linear parameters. The calculation for the total Bjork angle included three angles. First the angle shaped by the $\mathrm{N}-\mathrm{S}$ and $\mathrm{S}-\mathrm{Ar}$ lines; second - the one created by the S-Ar and Ar-Go lines; third - the one that the Ar-Go and Go-Me lines shaped. The front face height was measured from the $\mathrm{N}$ (na- neutral growth type is $69-77^{\circ}$, whereas the Ricketts face angle varies between $89-92^{\circ}$. Besides, we considered the angles determining the jaws position in relation to the skull (ANS and BNS). The position of the articular head was identified vertically $(\mathrm{S}-\mathrm{D})$ and horizontally $(\mathrm{C}-\mathrm{D})$, where the $\mathrm{D}$ point was the intersection of a perpendicular line to the skull base plane at the $S$ point, and a perpendicular line drawn to it from the $\mathrm{C}$ point. 
The teleradiographic data was recorded in $\mathrm{Mi}$ crosoft Excel spreadsheets. The results were computerprocessed employing standard software packages with the variation statistics method and calculating the arithmetic mean as well as identifying the nonsampling error.

\section{RESULTS AND DISCUSSION}

The most objective indicator for the facial part growth type is the lower jaw angle shaped by the tangent lines to the jaw's body and branch. Its size, as a rule, affects the total Bjork angle, the front height of the face, the angles created by the mandibular plane and other planes of the head - the skull base plane, the spinal plane, the occlusal plane. The mandibular angle determines the parameters of the lower gonial angle $(\mathrm{N}-\mathrm{Go}-\mathrm{Me})$ and the Ricketts face angle. Fig. 2 offers a view on various teleroentgenograms with different values of the mandibular angle. in terms of the ANS angle, which determines the location of the maxilla in the skull facial part. People with physiological occlusion have it varying from $85^{\circ}$ to $88^{\circ}$. The parameters of the BNS angle are somewhat smaller, yet, they, too, proved not to depend on the growth type of the facial part of the head. The variability of the ANB angle was within $2-3^{\circ}$. A slight increase in the angle is typical of people with the vertical growth type, while a decrease was observed in case of the horizontal growth type of the head facial part. Notable is the inconsistency of the total Bjork angle as it is determined here. For all types of growth, it was below the values that are to be found in the respective literature. Nevertheless, there were significant differences identified concerning the parameters of the groups under examination. In people with the neutral growth type, the angle varied from $380^{\circ}$ to $384^{\circ}$. A smaller angle was typical for the horizontal growth, whereas an increase for the vertical type. The
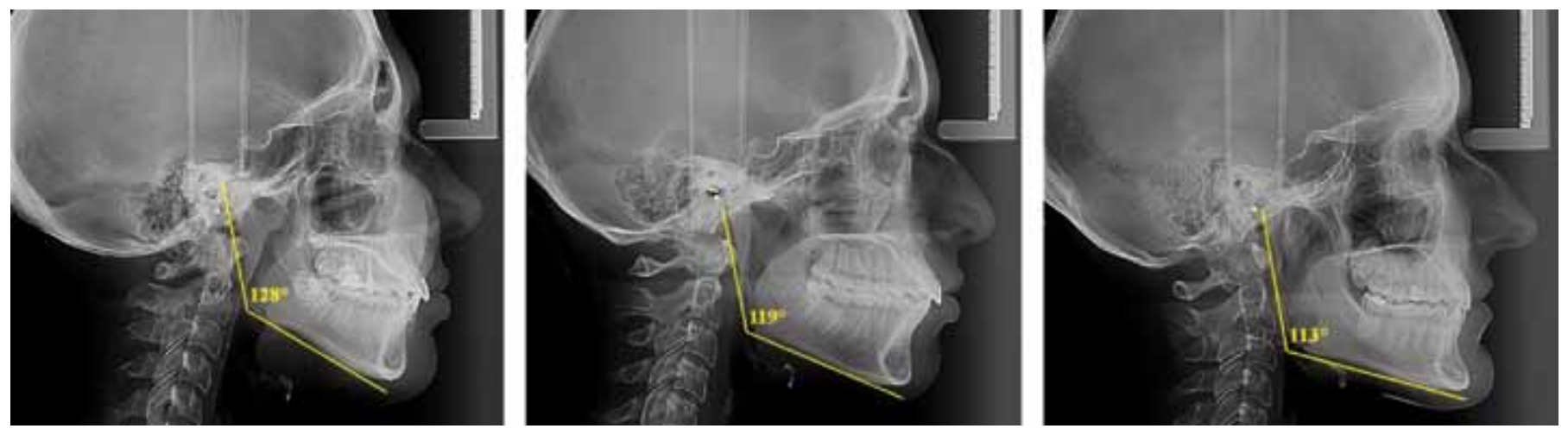

Fig. 2. Teleroentgenograms of patients with the vertical (a), the neutral (b) and the horizontal (c) type of jaw growth

Of the total number of the participants with physiological occlusion, 181 persons $(61.99 \pm 2.84 \%)$ had most of their growth-type indicators corresponding the neutral values. 89 persons were identified ( $30.48 \pm 2.69 \%$ of the total body of participants) as having parameters pointing at the horizontal growth type. The smallest number of patients were those with the vertical type of growth $(22$ persons $-7.53 \pm$ $1.55 \%$ of the total number). During that, the trend of the vertical growth was insignificant.

The measurements for the angular parameters of the lateral projection teleradiography can be seen from Table 1.

The study showed that, regardless of the growth type of the facial part of the head, the position of the jaws in relation to the main anatomical references corresponded to the physiological norm. There were no significant differences identified between the groups differences in the mandibular angle had their effect on the lower gonial angle (NGoMe) parameters. For the neutral growth type, its value ranged from $69^{\circ}$ to $74^{\circ}$ and corresponded to the values obtained through the study. Also, significant differences were revealed based on the angle between the skull base plane and the mandibular line. For the neutral growth type, the value of the parameter was $29.39 \pm 1.75^{\circ}$. In people with the neutral type of growth the Ricketts face angle is approaching the right angle. As far as the horizontal type of growth is concerned, the angle is obtuse; in case of the vertical type of growth - sharp. It is interesting to look at the angle shaped by the occlusal and mandibular planes. For the neutral type of growth, its value varied from $14^{\circ}$ to $16^{\circ}$. The systematization of the data allowed establishing the teleroentgenograms basic angular parameters, which are typical of persons with different growth types of the facial part of the head. 
Table 1. Major angular teleroentgenogram parameters for people with different facial part growth, $\left({ }^{\circ}\right),(M \pm m),(p \leq 0,05)$

\begin{tabular}{l|l|l|l}
\hline \multirow{2}{*}{$\begin{array}{l}\text { Angular teleroentge- } \\
\text { nogram parameters }\end{array}$} & \multicolumn{3}{|l}{ Type of facial part growth } \\
\cline { 2 - 4 } & neutral & horizontal & vertical \\
\hline Bjork angle & $382.06 \pm 2.06$ & $375.33 \pm 1.27$ & $388.53 \pm 1.67$ \\
\hline N-Go-Me angle & $71.61 \pm 1.98$ & $64.33 \pm 1.26$ & $79.15 \pm 1.82$ \\
\hline Mandibular angle & $120.07 \pm 1.24$ & $113.22 \pm 0.84$ & $127.65 \pm 1.68$ \\
\hline NL - ML angle & $29.39 \pm 1.75$ & $19.78 \pm 1.92$ & $36.48 \pm 2.87$ \\
\hline OL - ML angle & $15.04 \pm 0.48$ & $9.02 \pm 0.88$ & $17.52 \pm 0.51$ \\
\hline Ricketts angle & $90.44 \pm 1.14$ & $98.89 \pm 1.39$ & $86.68 \pm 1.38$ \\
\hline ANS angle & $87.11 \pm 1.21$ & $87.33 \pm 1.15$ & $86.52 \pm 1.34$ \\
\hline BNS angle & $84.17 \pm 1.35$ & $85.67 \pm 1.46$ & $82.38 \pm 1.96$ \\
\hline ANB angle & $2.94 \pm 0.81$ & $1.67 \pm 0.96$ & $4.12 \pm 1.83$ \\
\hline
\end{tabular}

In addition, we evaluated the linear parameters of the teleradiography, in particular, the height of the anterior and posterior parts of the face, as well as we evaluated their ratio. Also, we evaluated the location of the mandible articular head with respect to the position of the Turkish saddle, both vertically and horizontally.

Table 2 offers the measurements for the teleroentgenograms linear parameters, lateral projection.

Table 2. Major linear parameters of teleroentgenograms for people with various facial growth types, $(\mathrm{mm}),(M \pm m),(p \leq 0.05)$

\begin{tabular}{l|l|l|l}
\hline \multirow{2}{*}{$\begin{array}{l}\text { Teleradiographic } \\
\text { linear parameters }\end{array}$} & \multicolumn{3}{|l}{ Growth types of facial part of head } \\
\cline { 2 - 4 } & neutral & horizontal & vertical \\
\hline N-Me (front height) & $115.04 \pm 1.64$ & $107.73 \pm 1.76$ & $118.49 \pm 1.72$ \\
\hline S-Go (rear height) & $76.06 \pm 1.39$ & $82.09 \pm 1.63$ & $72.51 \pm 1.44$ \\
\hline S-D (vertical) & $19.27 \pm 1.35$ & $20.09 \pm 1.29$ & $17.47 \pm 1.54$ \\
\hline C-D (sagittal) & $14.17 \pm 1.21$ & $12.61 \pm 1.18$ & $11.79 \pm 1.23$ \\
\hline
\end{tabular}

The front height of the face in people with the horizontal type of growth was significantly below than that in the vertical type. At the same time, the height of the rear face area in people with the horizontal type of growth exceeded that in people with the vertical type of the face growth. In this regard, the percentage ratio of these parameters changed. The value of the S-Go $\times 100 / \mathrm{N}-\mathrm{Me}$ ratio was: for the neutral growth type of the facial part of the head $-71.61 \pm 0.98 \%$; for the horizontal type $-76.24 \pm 1.64 \%$; for the vertical type $-61.18 \pm 1.64 \%$. The groups of participants manifested no statistically reliable differences in the articular heads location in relation to the skull base and, in particular, related to the Turkish saddle.

\section{CONCLUSIONS}

1. The teleroentgenogram head measurements in the lateral projection are objective and informative when studying the size and location of the face skull bones, as well as the main growth directions of the head facial part.

2. The growth types of the facial part of the head are determined by the teleroentgenogram basic linear and angular parameters, as well as by the main types of the jaw growth.

3. With the physiological occlusion, there have been three main types identified for the growth of the head facial part; their distribution, however, is uneven. The highest number of people with physiological occlusion manifested the teleradiographic values pertaining to the neutral type of growth (181 people $-61.99 \pm 2.84 \%$ of the total number). 89 participants were identified to have indicators pointing at the horizontal type of growth $(30.48 \pm 2.69 \%)$. The lowest number of the participants belonged to the group with the vertical growth type (22 persons - $7.53 \pm 1.55 \%$ ).

4 . The study has revealed no stable tendency detected towards the vertical growth of the facial part of the head.

\section{REFERENCES}

1. DAVYdov B.N., DMitrienKo S.V., DOMENYUK D.A., Porfiriadis M.P, Budaychiev G.M.-A. Results of integrated estimation of the functional state of the dentistry system in patients with physiological occlusion of tooth rows (Part I). The Dental Institute. 2017; 77(4):78-82. (In Russ.).

2. Davydov B.N., Vedeshina E.G., DMitrienko S.V., DomenYUK D.A. Factors determining choice of metal arches and braces specification in edgewise technique-based orthodontic treatment (Part I). The Dental Institute. 2015; 69(4):92-93. (In Russ.).

3. Davydov B.N., Vedeshina E.G., DMitrienko S.V., Domenyuk D.A. Factors determining choice of metal arches and braces specification in edgewise technique-based orthodontic treatment (Part II). The Dental Institute. 2016; 70(1):54-57. (In Russ.).

4. Davydov B.N., Vedeshina E.G., DMitrienko S.V., DomenYuk D.A. Radiological and morphometric methods for comprehensive assessment of cephalo-odontologic status in dental patients (Part I). The Dental Institute. 2017; 75(2):58-61. (In Russ.).

5. Davydov B.N., Vedeshina E.G., DMitrienko S.V., DomenYuk D.A. Radiological and morphometric methods for comprehensive assessment of cephalo-odontologic status in dental patients (Part II). The Dental Institute. 2017; 76(3): 32-35. (In Russ.).

6. DAVydov B.N., DoMENYUK D.A., Vedeshina E.G., DMitrienko S.V. Biometric justification of main linear dimensions of the dental arches in ortho- 
dontic treatment tactics' development using edgewise orthodontic technique (Part I). The Dental Institute. 2016;1(70):76-78. (In Russ.).

7. Davydov B.N., Domenyuk D.A., Vedeshina E.G., DMitrienko S.V. Biometric justification of main linear dimensions of the dental arches in orthodontic treatment tactics' development using edgewise orthodontic technique (Part II). The Dental Institute. 2016;2(71):66-67.

8. Davydov B.N., Domenyuk D.A., Porfyriadis M.P., Vedeshina E.G., DMitrienKo S.V. Features of tactics and principles orthodontic treatment of patients with dental arches asymmetry caused by different amounts of antimeres (Part I). The Dental Institute. 2017;4(77):64-68.

9. DMitrienko S.V., Domenyuk D.A., KochKonyan A.S., Karslieva A.G., DMitrienko D.S. Interrelation between sagittal and transversal sizes in form variations of maxillary dental arches // Archiv EuroMedica, 2014. - Vol. 4. - No 2. - P. 10-13.

10. DMitrienko S.V., Domenyuk D.A., Vedeshina E.G. Shape individualization in lower dental arches drawn on basic morphometric features // Archiv EuroMedica, 2015. - Vol. 5. - No 1. - P. 11-15.

11. Domenyuk D.A., Dmitrienko S.V., Vedeshina E.G., Porfyriadis M.P., Budaychiev G.M-A. Analytical approach in evaluating the relations of odontometric indicators and linear parameters of dental arcs in people with various face types. Kubanskij nauchnyj medicinskij vestnik. 2018; 25(1): 73-81. (In Russ., English abstract). DOI: 10.25207 / 1608-62282018-25-1-73-81.

12. Domenyuk D.A., Vedeshina E.G., Dmitrienko S.V. Anatomic and topographic rationale for dental arch constructing and measuring methods. Kubanskij nauchnyj medicinskij vestnik. 2015;(3):31-37. (In Russ.) DOI:10.25207/1608-6228-2015-3-31-37.

13. Domenyuk D.A., Shkarin V.V., Porfiriadis M.P., DMitrienko D.S., DMitrienko S.V. Classification of facial types in view of gnathology // Archiv EuroMedica, 2017. - T.7. - No 1. - C. 8-13.

14. Domenyuk D.A., Vedeshina E.G., Dmitrienko S.V., Orfanova Z.S. Comparative analysis of dentoalveolar arch morphometric parameters in case of arch shape variations. Kubanskij nauchnyj medicinskij vestnik. 2015;(2):63-69. (In Russ.) DOI:10.25207/1608-6228-2015-2-63-69.

15. Domenyuk D.A., Vedeshina E.G., Dmitrienko S.V. Correlation of dental arch major linear parameters and odontometric indices given physiological occlusion of permanent teeth in various face types // Archiv EuroMedica, 2016. - Vol. 6. - No 2. - P. 18-22.

16. Domenyuk D.A., Vedeshina E.G., Dmitrienko S.V. Dynamics of changes in transverse and frontalretromolar jaw sizes in children throughout the orthodontic treatment stages. Kubanskij nauchnyj medicinskij vestnik. 2016;(3):51-59. (In Russ.) DOI:10.25207/1608-6228-2016-3-51-59.
17. Domenyuk D.A., Vedeshina E.G., DMitrienko S.V. Efficiency evaluation for comprehensive treatment of patients with dental arches asymmetry at similar number of antimeres. Kubanskij nauchnyj medicinskij vestnik. 2016;(6):42-54. (In Russ.) DOI:10.25207/1608-6228-2016-6-42-54.

18. Domenyuk D.A., Vedeshina E.G., Dmitrienko S.V. Efficiency evaluation for integrated approach to choice of orthodontic and prosthetic treatments in patients with reduced gnathic region // Archiv EuroMedica. - 2015. - Vol. 5. - No 2. - P. 6-12.

19. Domenyuk D.A., ShKarin V.V., Porfyriadis M.P., DMitrienko D.S., DMitrienKo S.V. Algorithm for forecasting the shape and size of dental arches front part in case of their deformations and anomalies // Archiv EuroMedica, 2017. - T. 7. - No 2. - C. 105-110.

20. Domenyuk D.A., Tashueva L.V., Zelensky V.A., IVANCHEVA E.N. Evaluation of microvasculature tissues viability after the imposition of removable orthodontic appliances in children and adolescents // Archiv EuroMedica, 2013. - Vol. 3. - No 1. - P. C. 5-9.

21. Domenyuk D.A., Vedeshina E.G., DMitrienko S.V. Mistakes in Pont (Linder-Harth) method used for diagnosing abnormal dental arches in transversal plane // Archiv EuroMedica, 2016. - Vol. 6. - No 2. - P. 23-26.

22. Domenyuk, D.A. Modern classification of dental arches / D.A. Domenyuk, S.V. Dmitrienko // Archiv EuroMedica, 2014. - Vol. 4. - No 2. - P. 14-16.

23. Domenyuk D.A., Vedeshina E.G. Morphometric parameters of brachygnathic dental arches considering size of permanent teeth. Kubanskij nauchnyj medicinskij vestnik. 2015;(6):47-53. (In Russ.) DOI:10.25207/1608-6228-2015-6-47-53.

24. Domenyuk D.A., Vedeshina E.G., Dmitrienko S.V. Special features of dolichognathic dental arches in people with teeth size variations. Kubanskij nauchnyj medicinskij vestnik. 2016;(1):39-46. (In Russ.) DOI:10.25207/1608-6228-2016-1-39-46.

25. Domenyuk D.A., Vedeshina E.G., Dmitrienko S.V. Teeth sizes in their correlation with parameters of dentofacial arches and maxillofacial area based on native cranial preparations examination. Kubanskij nauchnyj medicinskij vestnik. 2016;(2):71-79. (In Russ.) DOI:10.25207/1608-6228-2016-2-71-79.

26. Domenyuk D.A., Vedeshina E.G., Dmitrienko S.V. The use of craniometric and morphological studies in the assessment of structural elements of the temporomandibular joint. Kubanskij nauchnyj medicinskij vestnik. 2017;1(1):33-40. (In Russ.) DOI:10.25207/1608-6228-2017-1-33-40.

27. Domenyuk, D.A. Semiquantitative evaluation of caries microflora in patients with dental and alveolar abnormalities and different severity of morphofunctional disturbances / D.A. Domenyuk, E.G. Vedeshina, V.A. Zelensky, K.G. Karakov, M.P. Porfiriadis // Medical news of North Caucasus. 2015. - Vol. 10. - № 3. - P. 238-241. (In Russ.) DOI: 10.14300/ mnnc.2015.10055. 28. Domenyuk D.A., Ilijev D.M., 
Budaychiev G.M-A., Vedeshina E.G., Dmitrienko S.V. Optimization of diagnostics and planning of orthodontic treatment of patients with dentofacial anomalies based on the results of morphometric studies of the anterior dental arch. Kubanskij nauchnyj medicinskij vestnik. 2017; 25(5): 14-21. (In Russ., English abstract). DOI: 10.25207 / 1608-6228-2017-24-5-14-21.

29. Domenyuk D.A., DMitrienko S.V., Vedeshina E.G., Risovanny S.I., Porfyriadis M.P., BudayCHIEV G.M-A. Methods of biometrical diagnostics in transversal direction in patients with mesognathic type of dental arches. Kubanskij nauchnyj medicinskij vestnik. 2017; 24(6): 26-34. (In Russ., English abstract). DOI: 10.25207 / 1608-6228-2017-24-6-26-34.

30. Domenyuk D.A., Dmitrienko S.V., Vedeshina E.G., Porfyriadis M.P., Budaychiev G.M-A. Analytical approach in evaluating the relations of odontometric indicators and linear parameters of dental arcs in people with various face types. Kubanskij nauchnyj medicinskij vestnik. 2018; 25(1): 73-81. (In Russ., English abstract). DOI: 10.25207 / 1608-62282018-25-1-73-81.

31. Domenyuk D.A., Porfyriadis M.P., IliJev D.M., BudAYChIEv G.M-A., VEDEShiNA E.G., DMitrienko S.V. Dimensional and topographic features of the elements of the temporomandibular joint with mesial occlusion complicated by dentition defects. Kubanskij nauchnyj medicinskij vestnik. 2017;24(4);54-64. (In Russ., English abstract). DOI: 10.25207 / 1608-6228-2017-24-4-54-64.

32. ZeLENSKY, V.A. Integral indicator for orthodontic carequality control / V.A. Zelensky, D.A. Domenyuk, M.V. Baturin, I.V. Zelensky, A.V. Kokareva, A.V. Zenina // Medical news of North Caucasus. 2014. Vol. 9. - No 1. - P. 80-83. (In Russ., English abstract). DOI: 10.14300/mnnc.2014.09022. 33. Karslieva A.G., Domenyuk D.A., Zelensky V.A. Mixed saliva trace element composition in children with dentoalveolar anomalies through apparatus-involved treatment // Archiv EuroMedica, 2014. - Vol. 4. - No 1. - P. $29-35$.

34. KorobkeEv, A.A. Changes in the structural elements of the temporomandibular joint with distal occlusion / A.A. Korobkeev, D.A. Domenyuk, E.G. Vedeshina, V.V. Konov, O.Yu. Lezhnina, Ya.A. Korobkeeva / / Medical news of North Caucasus. 2017. - Vol. 12. - No 1. - P. 72-76. (In Russ., English abstract). DOI: 10.14300/mnnc.2017.12020.

35. KorobkeEv, A.A. The main forms of individual microdontia formed in the mixed dentition of permanent teeth / A.A. Korobkeev, D.A. Domenyuk, E.G. Vedeshina, S.B. Fischev, O.Yu. Lezhnina, Ya.A. Korobkeeva / / Medical news of North Caucasus. 2016. - Vol. 11. - No 3. - P. 474-476. (In Russ., English abstract). DOI: 10.14300/mnnc.2016.11110.

36. Shkarin V.V., Domenyuk D.A., Porfiriadis M.P., DMitrienko D.S., DMitrienko S.V. Mathematical and graphics simulation for individual shape of maxillary dental arch // Archiv EuroMedica, 2017. - T.7. - No 1. - C. 60-65.
37. Vedeshina E.G., Domenyuk D.A., DMitrienko S.V. Anatomic features of inclination and angulation of permanent teeth in case of different mesognathic dental arches. Kubanskij nauchnyj medicinskij vestnik. 2016;(1):16-23. (In Russ.) DOI:10.25207/1608-62282016-1-16-23.

38. Vedeshina E.G., Domenyuk D.A., Dmitrienko S.V. Correlation between shapes and sizes of dentofacial arches and their stable parameters. Kubanskij nauchnyj medicinskij vestnik. 2016;(3):33-38. (In Russ.) DOI:10.25207/1608-6228-2016-3-33-38.

39. Vedeshina E.G., Domenyuk D.A., Dmitrienko S.V. Determining torque and angulation of permanent teeth in cases of brachygnathic dental arches depending on dentition type. Kubanskij nauchnyj medicinskij vestnik. 2015;(6):23-30. (In Russ.) DOI:10.25207/1608-6228-2015-6-23-30.

40. Vedeshina E.G., Domenyuk D.A., DMitrienko S.V., Orfanova Z.S. Geometrical and graphic validation for patient management selection criteria in dental arches asymmetry. Kubanskij nauchnyj medicinskij vestnik. 2015;(2):23-28. (In Russ.) DOI:10.25207/1608-6228-2015-2-23-28.

41. Vedeshina E.G., Domenyuk D.A., DMitrienko S.V., DMitrienko D.S., Nalbandyan L.V., GaGLOYEVA N.F. Odontometric parameters in cases with mesognathic dental arches. Kubanskij nauchnyj medicinskij vestnik. 2015;(4):44-48. (In Russ.) DOI:10.25207/1608-6228-2015-4-44-48.

42. Shkarin V.V., Porfiriadis M.P., Domenyuk D.A., DMitrienko D.S., DMitrienko S.V. Setting reference points for key teeth location in case of abnormal dental arch shape //Archiv EuroMedica. - 2017. - V.7. - No 2. - C. 111-117. 